\title{
DESAIN ULANG STRUKTUR DROP PANEL JOGJA APARTEMEN DIGANTIKAN DENGAN STRUKTUR BALOK MENGGUNAKAN SNI 2847:2013 DAN SNI
}

\section{6:2012}

\author{
oleh : \\ Yoga Aprianto Harsoyo \\ Teknik Sipil Universitas Muhammadiyah Yogyakarta \\ Email : yogaharsoyo@umy.ac.id \\ Irwan Setyo Wibowo \\ Teknik Sipil Universitas Muhammadiyah Yogyakarta \\ Email : irwansetyowib@gmail.com
}

\begin{abstract}
Abstrak : Perkembangan teknologi beton membuat ikut berkembangnya struktur beton bertulang. Salah satunya adalah struktur drop panel. Drop panel merupakan struktur pengganti balok yang diproyeksikan dibawah flat slab dengan penambahan ketebalan pada kepala kolomnya. Namun, peraturan-paraturan yang menjelaskan tentang struktur ini masih sedikit, sehingga SNI 2847 : 2013 dan SNI 1726 : 2012 memberi batasan pada struktur drop panel dan flat slab hanya dapat digunakan pada struktur rangka pemikul momen menengah dan digunakan pada wilayah gempa ringan atau sedang. Jogja Apartemen termasuk ke dalam struktur rangka pemikul momen khusus dan berada pada wilayah gempa tinggi. Oleh karena itu dilakukan penelitian dengan mendesain ulang struktur drop panel Jogja Apartemen digantikan dengan balok konvensional untuk mendapatkan tingkat keamanan struktur terhadap parameter-parameter beban gempa, persyaratan beton bertulang, perbandingan dimensi awal drop panel, balok, dan flat slab dengan desain baru dan memperoleh perbandingan rasio volume beton bertulang. Penelitian ini dilakukan dengan merubah perencanaan drop panel dan balok awal dengan balok baru tanpa drop panel yang dibantu dengan software analisis numerik ETABS. Dari hasil penelitian didapat bahwa desain denah balok baru tanpa drop panel dinyatakan aman terhadap parameterparameter beban gempa berupa periode getar struktur dengan nilai arah $\mathrm{x}$ dan y di bawah batas maksimum sebesar 2,03 detik, base shear dimana $\mathrm{V}$ dinamik lebih besar dari $85 \% \mathrm{~V}$ statik, perpindahan maksimum arah x dan y di bawah batas limit, stabilitas rasio pengaruh P-delta kurang dari nilai maksimum sebesar 0,091, faktor pembesaran torsi kurang dari 3, dan mengalami penurunan volume beton sebesar $16,27 \%$ dengan rasio tulangan mengalami penurunan sebesar $12,62 \%$.
\end{abstract}

Kata Kunci : drop panel, desain ulang, balok, beban gempa, keamanan

\begin{abstract}
The development of concrete technology makes the development of reinforced concrete structures. One of them is a drop panel structure. The drop panel is a beam replacement structure that is projected under a flat slab by adding thickness to the column head. However, the rules explain that structure are still few, SNI 2847:2013 and SNI 1726:2012 Provide limitation on drop panel structure and flat slab can only be used on medium moment thought structures and used in the Mild or moderate earthquake areas. Jogja Apartment is included in the structure of the special moments of the high earthquake area. Therefore research by redesigning the drop panel structure replaced with conventional beam to obtain the level of safety structure to parameters earthquake load, reinforced concrete requirements, comparison of the initial dimensions of drop panels, beams, and flat slab with a new design and obtaining comparisons of reinforced concrete volume ratios. This research is changing the plan drop
\end{abstract}


panel and the initial beam with a new beam plan without the drop panel assisted by ETABS numerical analysis software. The results of the research gained that the new beam floor design without a drop panel was declared safe against the parameters earthquake load parameters in the form of vibration period structure with $x$ and $y$ of direction below the maximum limit of 2.03 seconds, base shear where $V$ dynamic Greater than $85 \%$ V static, the maximum displacement of the $x$ and $y$ directions under the limit, the stability of the P-delta effect ratio is less than the maximum of 0.091, the torque enlargement factor is less than 3 , and the concrete volume the ratio of reinforcement decreases by $16.27 \%$ and $12.62 \%$.

Keywords: drop panels, redesign, beam, earthquake load, safety.

\section{Pendahuluan}

Semakin berkembangnya inovasi di dunia arsitektur membuat ikut berkembangnya satuktur bangunan gedung, salah satunya struktur drop panel dan flat slab. BSN (2013) menjelaskan bahwa panel drop (drop panel) adalah struktur yang diproyeksikan di bawah flat slab yang digunakan untuk mengurangi jumlah tulangan negatif sepanjang kolom atau tebal pelat perlu minimum, dan untuk meningkatkan geser slab. BSN (2013) menjelaskan bahwa flat slab adalah komponen struktur lentur menerus untuk momen positif dan negatif kritis.

Flat slab memiliki kelemahan terutama jika dibangun di daerah gempa. Perilaku dan metoda desain flat slab terhadap beban gravitasi telah dikenal dengan baik, tetapi terhadap beban lateral beberapa masalah belum dapat dirumuskan dengan pasti (Dovich dan Weght, 2005). Kelemahan tersebut mengakibatkan ditetapkannya pembatasan penggunaan flat slab. ASCE 705 menetapkan batasan tinggi maksimum untuk struktur flat slab (dalam hal ini belum ada pembatasan dalam SNI) SNI 2847:2013 memasukan flat slab ke dalam struktur rangka pemikul momen menengah dengan konsekuen flat slab sebagai single system hanya dapat digunakan pada wilayah gempa ringan atau sedang.

Melihat dari beberapa kelemahan tersebut penelitian ini menggunakan struktur balok konvensional sebagai pengganti flat slab karena dirasa lebih aman melihat struktur bangunan termasuk struktur rangka pemikul momen khusus dan termasuk kategori resiko struktur bangunan III dan IV. Desain balok yang diteliti memiliki bentuk dan letak yang berbeda beda pada setiap lantai dan ruangan melihat dari luas pelat lantai dan beban yang diterima. Desain ulang dilakukan untuk menganalisa perbedaan balok awal yang sudah ada dan ketebalan pelat lantai. Desain ulang dilakukan terhadap gedung Jogja Apartemen yang menggunakan struktur flat slab dan drop panel. Redesain dilakukan menggunakan peraturan SNI 2847:2013 untuk struktur beton bertulang, SNI 2052:2017 untuk tulangan baja yang digunakan, PPPURG 1989 dan SNI 1727:2013 untuk analisis pembebanan serta SNI 1726:2012 untuk beban gempa. Bangunan Jogja Apartemen dapat dilihat pada Gambar 1.

BSN (2013) menjelaskan bahwa balok harus dirancang terhadap 4 analisis yaitu : (1) kapasitas lentur balok (2) kapasitas geser balok (3) kapasitas puntir torsi dan (4) kapasitas sambungan balok kolom. Struktur balok banyak ditemui di lapangan baik gedung bertingkat rendah maupun tinggi sehingga dilakukan penelitian desain ulang pada gedung bertingkat tinggi menggunakan struktur balok menggantikan struktur flat slab dan drop panel guna 
megetahui tingkat kalayanan stktur bangunan terutama tehadap gempa bumi.

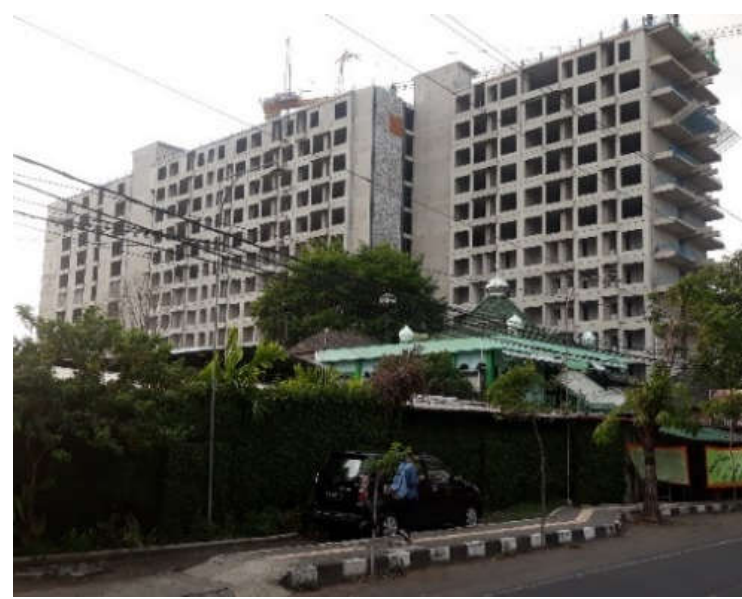

Gambar 1. Bangunan Jogja Apartemen

( Sumber : Proyek Jogja Apartemen 2020)

Gedung Jogja Apartemen yang ditinjau ini terletak di jalan Lowanu No 69, Sorosutan, Umbulharjo, Kota Yogyakarta, Daerah Istimewa Yogyakarta. Gedung yang sedang dibangun ini terdiri dari 12 lantai, 1 semibasemen, dan 1 basemen dengan tinggi total terhitung dari muka tanah 40,75 meter dan dengan tinggi rata rata setiap lantai 3,25 meter. Denah lokasi gedung yang ditinjau ditujukan pada Gambar 2.

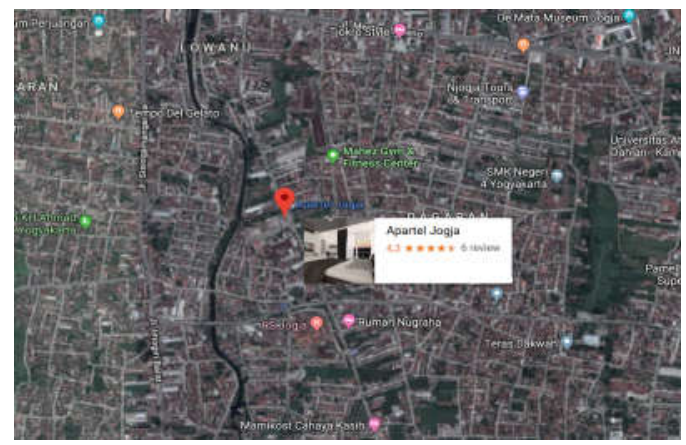

Gambar 2. Lokasi Gedung Jogja Apartemen

(Sumber : View google maps)

\section{Metodologi Penelitian}

Penelitian ini ini dilakukan dengan cara meredesain drop panel dan flat slab yang merupakan struktur awal pelat lantai gedung Jogja apartemen. Redesain dilakukan dengan 5 tahapan yaitu pengumpulan data, membuat denah balok, mengolah data gempa, pemodelan menggunakan software, perhitungan pembebanan dan analisa manual yang dilakukan secara manual menggunakan program, yang dapat dilihat pada Gambar 3. Dari 5 tahapan yang telah dilakukan didapatkan penampang optimal hasil desain ulang yang kemudian dibandingkan dengan penampang desain awal guna mendapatkan perbandingan volume beton dan tulangan baja.

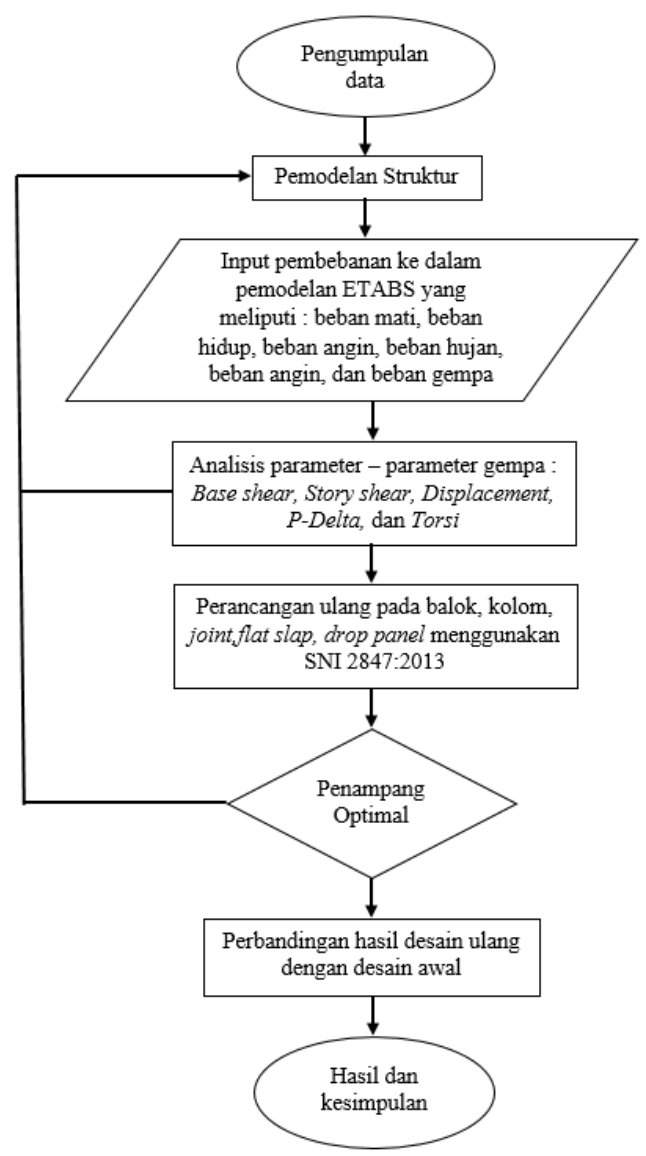

Gambar 3. Kerangka Konseptual ( Sumber : Analisis penulis 2020)

\section{Pengumpulan Data}

Eden dkk (2019) mengumpulkan data penelitian berupa data tanah, denah, detail dan standar. Data tanah berupa data borlog, data denah berupa denah rencana drop 
panel, flat slab, kolom, shearwall, data detail berupa detail penulangan kolom, shear wall, flat slab, drop panel, data standar berupa SNI 2847:2013, SNI 1726:2012, SNI 2052:2017, 03-1727:1989 dan SNI 1727:2013.

\section{Membuat Denah Balok}

Denah awal yang menggunakan drop panel dapat dilihat pada Gambar 4. dan denah baru yang menggunakan struktur balok dapat dilihat pada Gambar 5.

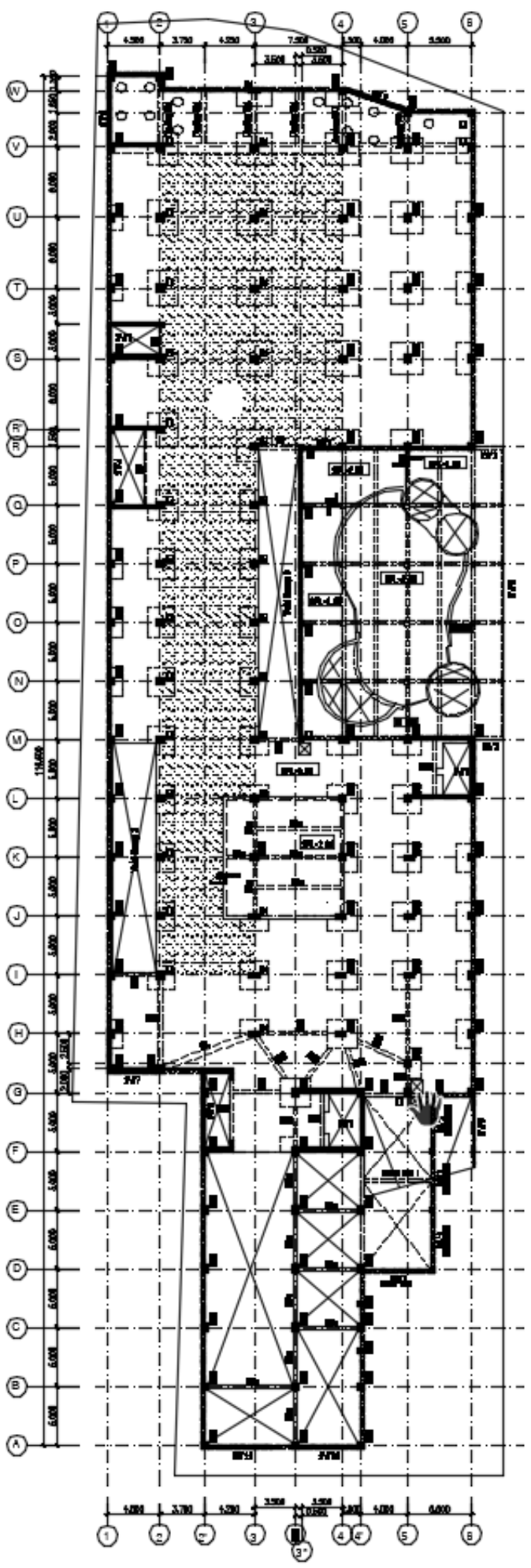

Gambar 4. Denah drop panel lantai 1 Jogja Apartemen

(Sumber : Data gambar proyek) 


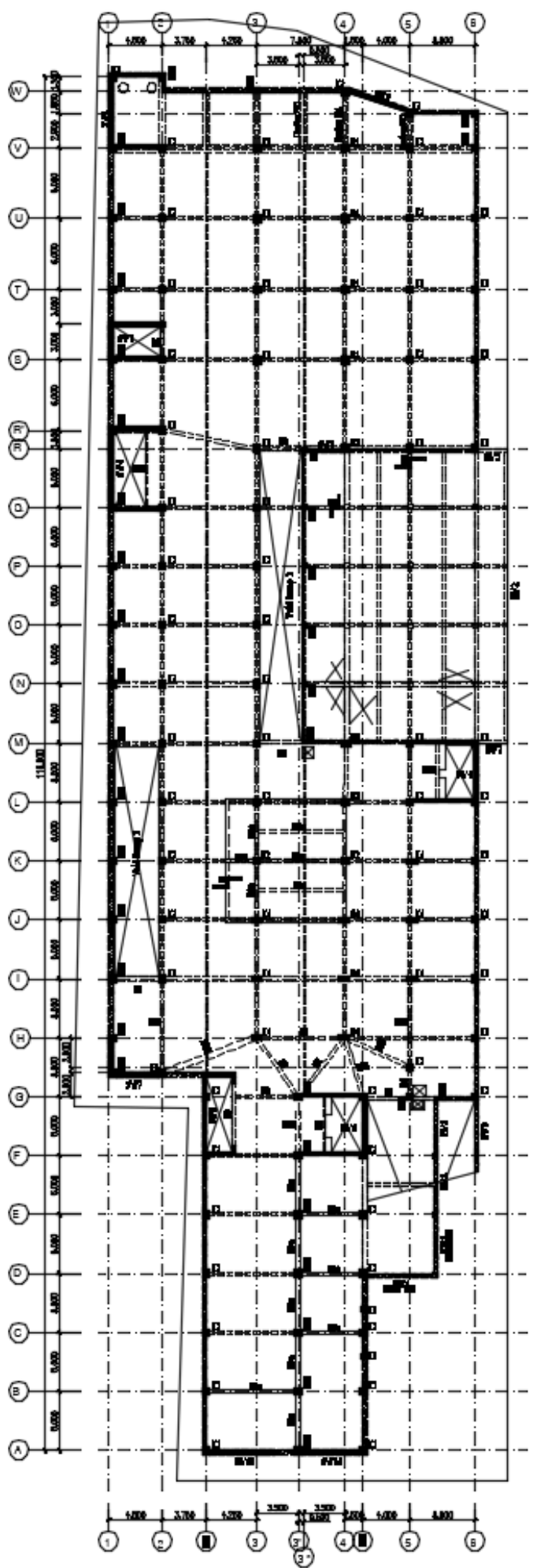

\section{Gambar 5. Denah Balok Lantai 1 Jogja Apartemen}

(Sumber : Desain gambar ulang penulis 2020)

\section{Mengolah Data Gempa}

Sidi dan Ma'sum (2017) melakukan penelitian terhadap menara baja dengan 40 data rekaman beban gempa. Sedangkan penelitian ini menggunakan 3 data rekaman beban gempa yang dimodifikasikan dengan respon spektrum. BSN (2012) menjelaskan Apabila analisis 3 dimensi dilakukan maka gerak tanah harus terdiri sepasang komponen percepatan tanah horisontal yang sesuai, yang harus diseleksi dan diskalakan dari rekaman peristiwa gempa individual. Bangunan tingkat tinggi atau di atas 10 lantai harus dianalisa terhadap parameter-parameter beban gempa yaitu : periode getar struktur, base shear, Story shear, Displacement, pengaruh P-Delta dan Torsi dan dianalisis mengunakan analisis non-linier rekaman beban gempa time history. Rekaman beban gempa yang digunakan harus 3 rekaman yang berbeda dan dimodifikasikan dengan respons spektrum. 3 rekaman gempa yang digunakan yaitu Elsentro, Kobe dan Tabas yang dapat dilihat pada Gambar 6.

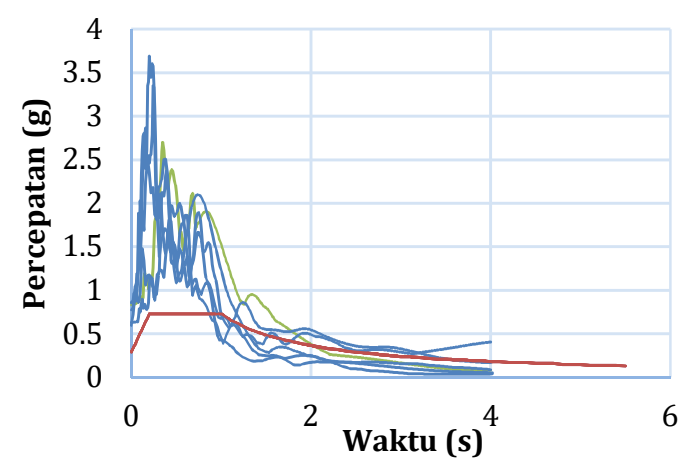

\section{Gambar 6. Akselelogram Sebelum} Dimodifikasi

(Sumber : Analisis penulis 2020 )

SNI 1726:2012 menjelaskan apabila rekaman gerak tanah yang tidak sesuai tidak mencakupi maka harus dibuat rekaman gerak tanah buatan, gerak tanah tersebut harus diskalakan sedemikian rupa sehingga nilai rata-rata spektrum respons 
dengan redaman $5 \%$ dari semua gerak tanah yang sesuai situs tersebut tidak boleh kurang dari spektrum respons desain setempat untuk rentang perioda dari $0,2 \mathrm{~T}$ hingga 1,5 $\mathrm{T}$, dimana $\mathrm{T}$ adalah perioda getar alami struktur dalam ragam getar fundamental untuk arah respon yang dianalisis. Hasil modifikasi rekaman gempa dengan respon spektrum dapat dilihat pada Gambar 7.

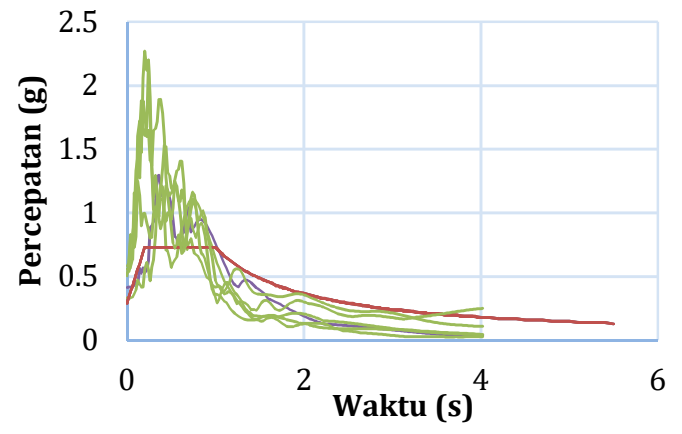

Gambar 7. Akselelogram Setelah Dimodifikasi

(Sumber : Analisis penulis 2020)

Pudjisuryadi dkk (2018) melakukan penelitiandengan memodelkan struktur gedung 9 lantai menggunakan software SAP 2000 dimana struktur balok dan kolom dimodelkan sebagai frame, shearwall dan pelat dimodelkan sebagai shell. Penelitian ini menggunakan software perhitungan numerik ETABS V 17. dengan balok dan kolom dimodelkan sebagai frame, pelat lantai dan shear wall dimodelkan sebagai shell untuk mendapatkan gaya dalam pada struktur balok, pelat dan parameter beban gempa yang dapat dilihat pada Gambar 8.

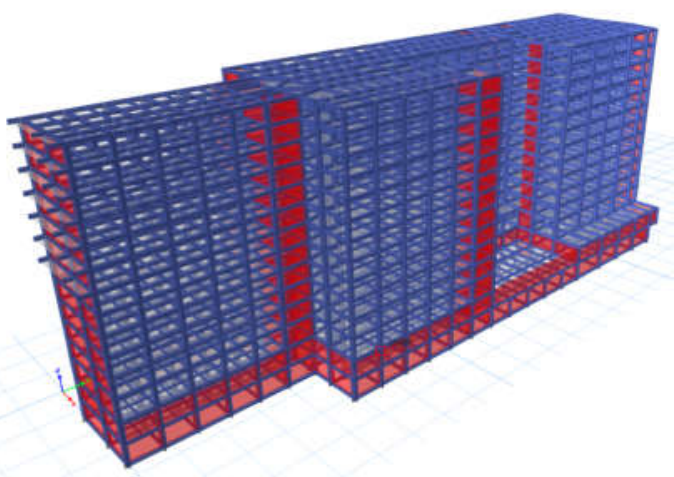

Gambar 8. Pemodelan struktur menggunakan ETABS

(Sumber : Analisis penulis 2020)

\section{Pendefiasian Beban Bekerja}

Penelitian yang dilakukan oleh Prabowo dan Lase (2017), Sukrawa (2014), Viswanathan dan Ganesh (2014) menggunakan tiga jenis beban yang bekerja yaitu beban hidup, beban mati, beban gempa. Beban yang digunakan dalam penelitian ini berupa beban mati tambahan (dinding, lantai, plafon, plumbing, dan mechanical). Beban hidup berupa beban pekerja, beban angin, beban hujan yang dihitung menggunakan SNI 1727:1989, SNI 1727:2013 dan SNI 1726:2012.

\section{Pembebanan}

Pembebanan pada model struktur terdiri atas pembebanan statik dan dinamik (gempa), beban dari atap (rangka dan penutup atap, plafon dan aksesoris), dan beban hidup orang luasan (Soelarso dan Baehaki, 2017). Sedangkan untuk beban gempa dibebankan secara statik ekivalen dan dinamik dengan metode riwayat waktu sesuai dengan SNI 1726:2012. Beban mati, hidup, hujan dan beban gempa digunakan dalam bentuk kombinasi. SNI 1726:2012 yang merupakan SNI untuk beban gempa meberikan 2 jenis kombinasi untuk metode beban ultimit dan kombinasi untuk metode 
tegangan ijin. Penelitian ini menggunakan kombinasi pembebanan untuk beban ultimit. Kombinasi pembebanan untuk metode beban ultimit dasarnya ada 7 kombinasi dimana pada kombinasi 5 dan 7 terdapat beban gempa. akibat pengaruh beban gempa kombinasi untuk metode ultimit didapat 21 kombinasi pembebanan seleuruh kombinasi pembebanan dapat dilihat pada persamaan 1 hingga 23 .
$1,4 \mathrm{D}$
$1,2 \mathrm{D}+1,6 \mathrm{~L}+0,5 \mathrm{R}$
$1,2 \mathrm{D}+1,6 \mathrm{R}+\mathrm{L}$
$1,2 \mathrm{D}+1,6 \mathrm{R}+0,5 \mathrm{~W}$
$1,2 \mathrm{D}+1,0 \mathrm{~W}+\mathrm{L}+0,5 \mathrm{R}$
$1,346 \mathrm{D}+\mathrm{L}+0,39 \mathrm{EX}+1,3 \mathrm{EY}$
$1,346 \mathrm{D}+\mathrm{L}+0,39 \mathrm{EX}-1,3 \mathrm{EY}$
$1,346 \mathrm{D}+\mathrm{L}-0,39 \mathrm{EX}+1,3 \mathrm{EY}$
$1,346 \mathrm{D}+\mathrm{L}-0,39 \mathrm{EX}-1,3 \mathrm{EY}$
$1,346 \mathrm{D}+\mathrm{L}+1,3 \mathrm{EX}+0,39 \mathrm{EY}$
$1,346 \mathrm{D}+\mathrm{L}+1,3 \mathrm{EX}-0,39 \mathrm{EY}$
$1,346 \mathrm{D}+\mathrm{L}-1,3 \mathrm{EX}+0,39 \mathrm{EY}$
$1,346 \mathrm{D}+\mathrm{L}-1,3 \mathrm{EX}-0,39 \mathrm{EY}$
$0,9 \mathrm{D}+1,0 \mathrm{~W}$
$0,753 \mathrm{D}+0,39 \mathrm{EX}+1,3 \mathrm{EY}$
$0,753 \mathrm{D}+0,39 \mathrm{EX}-1,3 \mathrm{EY}$
$0,753 \mathrm{D}-0,39 \mathrm{EX}+1,3 \mathrm{EY}$
$0,753 \mathrm{D}-0,39 \mathrm{EX}-1,3 \mathrm{EY}$
$0,753 \mathrm{D}+1,3 \mathrm{EX}+0,39 \mathrm{EY}$
$0,753 \mathrm{D}+1,3 \mathrm{EX}-0,39 \mathrm{EY}$
$0,753 \mathrm{D}-1,3 \mathrm{EX}+0,39 \mathrm{EY}$
$0,753 \mathrm{D}-1,3 \mathrm{EX}-0,39 \mathrm{EY}$

\section{Analisa Manual}

Gunawan dkk (2019) dalam penelitiannya melakukan analisa terhadap struktur hubungan pelat - kolom pada struktur flat slab terhadap beban grafitasi dan lateral gempa menggunakan peraturan ACI 352,1R-89 dan ASCE 7-05 dengan tujuan mendapat tingkat keamanan sambungan pelat - kolom. Budiono dan Wicaksono (2016) melakukan analisa terhadap analisis gedung dengan struktur beton bertulang 20 lantai terhadap ketidakberaturan struktur dan displacement. Menggunakan SNI 2847:2012 untuk analisis beban gempa dan SNI 2847:2002 untuk analisis struktur beton bertulang dan dimodelkan dengan soft ware perhitungan numerik SAP 2000. Sedangkan penelitian ini melakukan analisa terhadap struktur gedung beton bertulang 14 lantai terhadap story shear, displacement, pengaruh $P$-Delta dan torsi dan dianalisis mengunakan analisis non-linier rekaman beban gempa time history dimodelkan dengan perangkat lunak perhitungan numerik ETABS. Analisa manual dilakukan untuk mendapakan beban yang akan diinputkan kedalam pemodelan serta analisis parameter beban gempa, perancangan balok dan pelat lantai digunakan SNI 1727:2013, SNI 1727:1989, SNI 1726:2012 dan SNI 2847:2013.

\section{Analisa Balok}

Denah awal bangunan dimodelkan ulang menggunakan balok rencana dengan dimensi balok induk (300 x 550), balok anak (200 x 300) , balok ring (300 x 500) dan tie beam (300 x 500) dengan bentang terpanjang 8 meter. Desain balok awal tetap digunakan hanya dianalisis kembali dengan mutu baja dan dimensi baru menyesuaikan dengan analisis gaya dalam. Analisa kapasitas tekan balok dianalisa terhadap Normal force Diagram, kapasitas geser balok dianalisa terhadap Shear Force Diagram, dan kapasitas lentur balok dianalisis terhadap Bending Momen Diagram. Output gaya dalam yang diperoleh dari analisis software ETABS dapat dilihat pada Gambar 9.

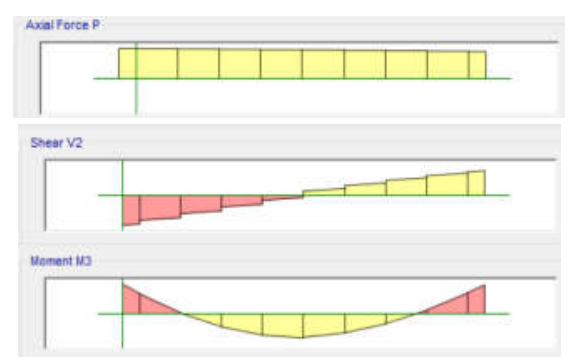

Gambar 9. Output gaya dalam balok (Sumber : Analisis penulis 2020) 


\section{Parameter Beban Gempa}

Penelitian membuahkan hasil dimana sesuai dengan yang diisyaratkan SNI 1726:2012 bahwa bangunan gedung tingkat tinggi atau berlantai banyak harus aman terhadap parameter-parameter beban gempa sebagai berikut :

\section{Perioda Getar Struktur}

Struktur bangunan yang didesain ulang dengan balok pada pemodelan menunjukkan perioda getar struktur pada arah X sebesar 1,479 dan pada arah Y 1,314 dimana batas minimum yang diisyaratkan untuk arah $\mathrm{X}$ sebesar 1,464 dan arah $\mathrm{Y}$ sebesar 1,464 sedangkan batas maksimum untuk arah X sebesar 2,049 dan arah Y sebesar 2,049. Dapat disimpulkan bahwa struktur ketika terkena beban gempa pada arah X termasuk balance tidak terlalu kaku dan daktail sedangkan arah Y struktur sedikit lebih kaku karena di bawah batas minimum yang diisyaratkan.

\section{Base shear}

Gaya geser dasar struktur yang didapat dari pemodelan untuk Vdinamik arah X sebesar 21.947,45 kN dan arah Y sebesar 13.060,13 sedangkan $\mathrm{V}$ statik arah $\mathrm{X}$ sebesar $16.784,262 \mathrm{kN}$ dan arah $\mathrm{Y}$ sebesar 16.784,262 dengan faktor pembesaran skala pada arah X sebesar 0 dan arah y sebesar 1,285 dimana diisyaratkan bahwa Vdinamik > Vstatik perbandingan gaya geser dasar struktur dapat dilihat pada Tabel 1 dan Tabel 2.

Tabel 1. Kontrol Skala Desain Awal

\begin{tabular}{cccccccc}
\hline $\begin{array}{c}\text { Arah } \\
\text { Gaya }\end{array}$ & $\begin{array}{c}\text { Skala faktor } \\
\text { awal }\end{array}$ & Vs $(\mathrm{kN})$ & $\begin{array}{c}85 \% \mathrm{Vs} \\
(\mathrm{kN})\end{array}$ & $\mathrm{Vd}(\mathrm{kN})$ & $\begin{array}{c}\text { Kontrol } \\
\mathrm{Vd} \geq 85 \% \mathrm{Vs}\end{array}$ & $\begin{array}{c}\text { Skala baru } \\
85 \% \mathrm{Vs} / \mathrm{Vd}\end{array}$ & $\begin{array}{c}\text { Skala awal } \\
\text { Skala baru }\end{array}$ \\
\hline $\mathrm{X}$ & 1,226 & $19.746,19$ & $16.784,26$ & $21.947,45$ & OK & - & 1,226 \\
$\mathrm{Y}$ & 1,226 & $19.746,19$ & $16.784,26$ & $13.060,13$ & $\mathrm{Tdk}$ OK & 1,285 & 1,576 \\
\hline
\end{tabular}

Sumber : Hasil Analisis (2020)

Tabel 2. Kontrol Skala Desain Baru

\begin{tabular}{ccccc}
\hline Arah Gaya & Vs $(\mathrm{kN})$ & $85 \%$ Vs $(\mathrm{kN})$ & Vd $(\mathrm{kN})$ & $\begin{array}{c}\text { Kontrol } \\
\mathrm{Vd} \geq 85 \% \mathrm{Vs}\end{array}$ \\
\hline $\mathrm{X}$ & $19.746,19$ & $16.784,262$ & $2.1947,45$ & OK \\
$\mathrm{Y}$ & $19.746,19$ & $16.784,262$ & $16.7845,13$ & OK \\
\hline
\end{tabular}

Sumber : Hasil Analisis (2020)

\section{Story shear}

Gaya geser setiap lantai perhitungan ekuivalen statik arah X dan Y dapat dilihat pada Gambar 10 dimana gaya geser pada setiap lantai pada arah X dan Y sama.

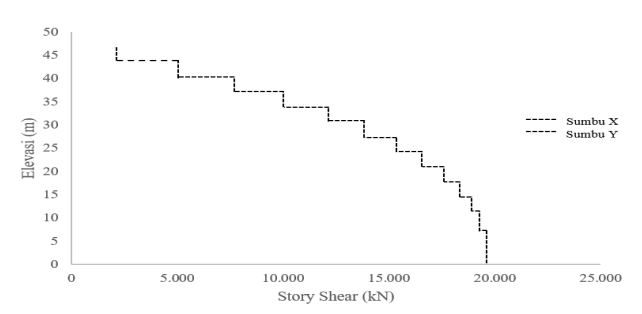

Gambar 10. Grafik Gaya Geser Untuk Statik Ekivalen

(Sumber : Analisis penulis 2020) 


\section{Partisipasi Massa Bangunan}

Dari analisis menggunakan software didapat modal participacing massa pada arah X sebesar (92,47 persen) dan pada arah $Y$ sebesar $(90,93$ persen) sesuai dengan yang diisyaratkan dalam peraturan bahwa partisipasi massa bangunan tidak boleh kurang dari (90 persen).

\section{Displacement}

Sesuai dengan peraturan yang diisyaratkan displacement struktur tidak melebihi batas limit baik antar lantai maupun komulatif dengan nilai maksimum pada lantai teratas arah $\mathrm{X}$ sebesar $15,06 \mathrm{~mm}$ dan arah $\mathrm{Y}$ sebesar 7,55 mm. Grafik displacement struktur dapat dilihat pada Gambar 11 dan Gambar 12.

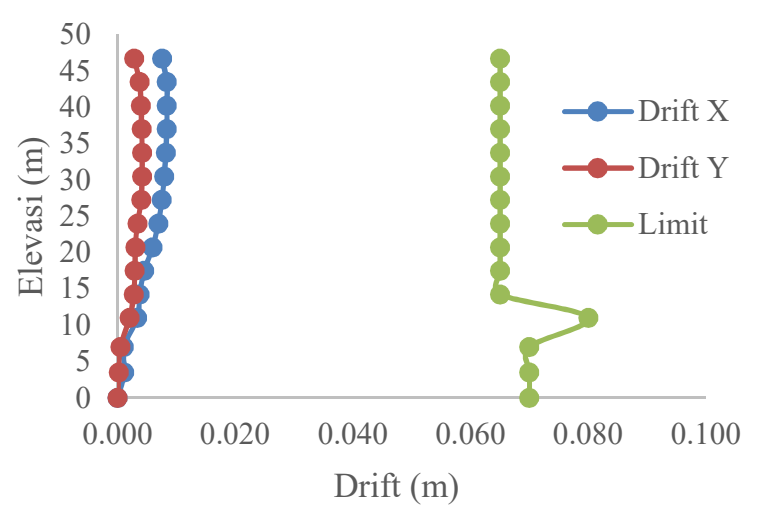

Gambar 11. Simpangan Antar Lantai (Sumber : Analisis penulis 2020)

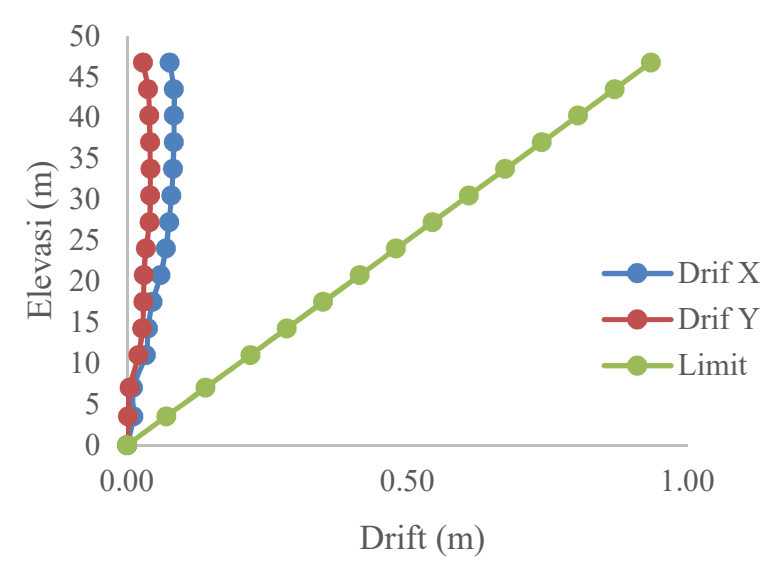

Gambar 12. Simpangan Komulatif Antar Lantai

(Sumber : Analisis penulis 2020)

\section{Pengaruh P-Delta}

Pengaruh P-Delta dan kontrol koefisien stabilitas $(\theta)$ dihitung untuk setiap lantai struktur gedung terhadap kedua arah yang ditinjau, kontrol koefisien stabilitas $(\theta)$ maksimum untuk arah X sebesar 0,066 dan untuk arah Y sebesar 0,035 tidak lebih besar dari koefisien stabilitas $(\theta)$ sebesar 0,91 untuk seluruh lantai pada arah X dan Y.

\section{Ketidakberaturan Struktur}

Eksentrisitas dari torsi atau ketidakberaturan struktur tak terduga adalah eksentrisitas tambahan $5 \%$ dari dimensi bangunan masing masing arah $\mathrm{X}$ dan arah Y. Struktur yang dirancang untuk kategori desain seismik D dimana tipe 1a atau $1 \mathrm{~b}$ ketidakberaturan torsi tidak terjadi dengan faktor pembesaran torsi sebesar 1 .

\section{Pelat}

Penelitian membuahkan hasil bahwa pelat yang didesain dengan struktur balok mengalami perubahan dimensi dan tulangannya dimana ketebalan pelat lantai mengalami penurunan sebesar 0,52 \% dan untuk perubahan luasan tulangan pelat mengalami penurunan sebesar 0,53 \%. Hal tersebut dikarenakan struktur drop panel digantikan dengan balok dan mutu baja tulangan menggunakan SNI 2052:2017. Detail dimensi dan tulangan pelat dapat dilihat pada Gambar 13.

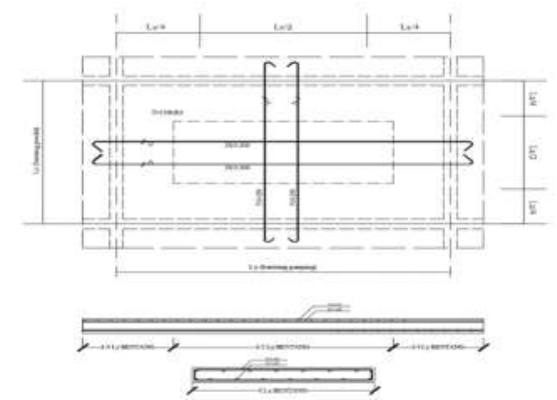

\section{Gambar 13. Detail Penulangan Pelat Lantai}

(Sumber : Analisis penulis 2020) 


\section{Balok}

Setelah struktur drop panel diganti dengan struktur balok, balok desain awal mengalami perubahan dimensi dan luasan tulangannya dimana pada dimensi balok mengalami penurunan sebesar 33,2 \% dan pada luasan tulangan mengalami penurunan sebesar 39,06\%. Perubahan dimensi disebabkan perbedaan ketebalan pelat lantai desain awal dengan desain ulang dan mutu tulangan baja desain ulang yang menggunakan SNI 2052:2017. Perubahan pada desain perencanaan awal dengan desain ulang dapat dilihat pada Tabel 3, 4 dan 5. dimana rasio tulangan dan dimensi perencanaan awal dibandingkan dengan rasio tulangan desain ulang.

Tabel 3. Perubahan dimensi balok

\begin{tabular}{ccccccccc}
\hline \multirow{3}{*}{ Balok } & \multicolumn{9}{c}{ Sebelum } & $\begin{array}{c}\text { Lebar } \\
(\mathrm{mm})\end{array}$ & $\begin{array}{c}\text { Tinggi } \\
(\mathrm{mm})\end{array}$ & Luas $\left(\mathrm{mm}^{2}\right)$ & $\begin{array}{c}\text { Lebar } \\
(\mathrm{mm})\end{array}$ & $\begin{array}{c}\text { Tinggi } \\
(\mathrm{mm})\end{array}$ & luas $\left(\mathrm{mm}^{2}\right)$ & $\begin{array}{c}\text { Perubahan } \\
\%\end{array}$ & Keterangan \\
\hline B1 & 500 & 550 & 275000 & 500 & 550 & 275000 & 0 & Tetap \\
B1a & 370 & 500 & 185000 & 300 & 500 & 150000 & 18,91 & Turun \\
B2 & 300 & 500 & 150000 & 300 & 500 & 150000 & 0 & Tetap \\
B3 & 300 & 500 & 150000 & 250 & 450 & 112500 & 25 & Turun \\
B3a & 300 & 500 & 150000 & 250 & 450 & 112500 & 25 & Turun \\
B4 & 350 & 500 & 175000 & 300 & 500 & 150000 & 14,28 & Turun \\
B5 & 200 & 400 & 80000 & 200 & 400 & 80000 & 0 & Tetap \\
B6 & 150 & 400 & 60000 & 150 & 400 & 60000 & 0 & Tetap \\
B Induk & - & - & - & 300 & 550 & 165000 & - & - \\
B Anak & - & - & - & 150 & 300 & 45000 & - & - \\
B Ring & - & - & - & 300 & 500 & 150000 & - & - \\
Balk & & & - & & & & & - \\
B Tie & - & - & - & 300 & 500 & 150000 & - & - \\
Beam & & & & & & & &
\end{tabular}

Tabel 4. Perbandingan Tulangan Tumpuan Balok Perancangan Ulang Dengan Desain Awal

\begin{tabular}{|c|c|c|c|c|c|c|c|c|c|c|}
\hline \multirow{3}{*}{ Balok } & \multicolumn{9}{|c|}{ Tumpuan } & \multirow{3}{*}{ Keterangan } \\
\hline & \multicolumn{4}{|c|}{ Sebelum } & \multicolumn{4}{|c|}{ Sebelum } & \multirow{2}{*}{$\begin{array}{c}\text { Perubahan } \\
(\%)\end{array}$} & \\
\hline & \multicolumn{3}{|c|}{ Tulangan } & \multirow{2}{*}{$\begin{array}{c}\begin{array}{c}\text { Luas } \\
\left(\mathrm{mm}^{2}\right)\end{array} \\
11290,1\end{array}$} & \multicolumn{3}{|c|}{ Tulangan } & \multirow{2}{*}{$\begin{array}{c}\begin{array}{c}\text { Luas } \\
\left(\mathrm{mm}^{2}\right)\end{array} \\
2551,759\end{array}$} & & \\
\hline B1 & 23 & $\mathrm{D}$ & 25 & & 9 & $\mathrm{D}$ & 19 & & 77,398 & Turun \\
\hline B1a & 13 & $\mathrm{D}$ & 25 & 6381,36 & 10 & $\mathrm{D}$ & 19 & 2835,287 & 55,569 & Turun \\
\hline B2 & 10 & $\mathrm{D}$ & 25 & 4908,74 & 11 & $\mathrm{D}$ & 19 & 3118,816 & 36,464 & Turun \\
\hline B3 & 9 & $\mathrm{D}$ & 19 & 2551,76 & 11 & $\mathrm{D}$ & 19 & 3118,816 & 22,222 & Naik \\
\hline B3a & 4 & $\mathrm{D}$ & 19 & 1134,11 & 8 & $\mathrm{D}$ & 19 & 2268,23 & 100 & Naik \\
\hline B4 & 6 & $\mathrm{D}$ & 25 & 2945,24 & 11 & $\mathrm{D}$ & 19 & 3118,816 & 5,893 & Naik \\
\hline B5 & 6 & D & 19 & 1701,17 & 8 & D & 19 & 2268,23 & 33,333 & Naik \\
\hline
\end{tabular}


Tabel 4 Lanjutan. Perbandingan Tulangan Tumpuan Balok Perancangan Ulang Dengan Desain Awal

\begin{tabular}{|c|c|c|c|c|c|c|c|c|c|c|}
\hline \multirow{3}{*}{ Balok } & \multicolumn{9}{|c|}{ Tumpuan } & \multirow{3}{*}{ Keterangan } \\
\hline & \multicolumn{4}{|c|}{ Sebelum } & \multicolumn{4}{|c|}{ Sebelum } & \multirow{2}{*}{$\begin{array}{c}\text { Perubahan } \\
(\%)\end{array}$} & \\
\hline & \multicolumn{3}{|c|}{ Tulangan } & \multirow{2}{*}{$\begin{array}{c}\begin{array}{c}\text { Luas } \\
\left(\mathrm{mm}^{2}\right)\end{array} \\
1701,17\end{array}$} & \multicolumn{3}{|c|}{ Tulangan } & \multirow{2}{*}{$\begin{array}{c}\begin{array}{c}\text { Luas } \\
\left(\mathrm{mm}^{2}\right)\end{array} \\
1608,495\end{array}$} & & \\
\hline B6 & 6 & $\mathrm{D}$ & 19 & & 8 & D & 16 & & 5,448 & Turun \\
\hline B induk & - & - & - & - & 12 & D & 19 & 3402,345 & - & - \\
\hline B Anak & - & - & - & - & 8 & D & 16 & 1608,495 & - & - \\
\hline B Ring Balk & - & - & - & - & 16 & D & 19 & 4536,46 & - & - \\
\hline B Tie Beam & - & - & - & - & 9 & D & 19 & 2551,759 & - & - \\
\hline
\end{tabular}

Tabel 5. Perbandingan Tulangan Lapangan Balok Perancangan Ulang Dengan Desain Awal

\begin{tabular}{|c|c|c|c|c|c|c|c|c|c|c|}
\hline \multirow{3}{*}{ Balok } & \multicolumn{9}{|c|}{ Lapangan } & \multirow{3}{*}{ Keterangan } \\
\hline & \multicolumn{4}{|c|}{ Sebelum } & \multicolumn{4}{|c|}{ Sebelum } & \multirow{2}{*}{$\begin{array}{c}\text { Perubahan } \\
(\%)\end{array}$} & \\
\hline & \multicolumn{3}{|c|}{ Tulangan } & \multirow{2}{*}{$\begin{array}{c}\text { Luas } \\
\left(\mathrm{mm}^{2}\right)\end{array}$} & \multicolumn{3}{|c|}{ Tulangan } & \multirow{2}{*}{$\begin{array}{c}\begin{array}{c}\text { Luas } \\
\left(\mathrm{mm}^{2}\right)\end{array} \\
2551,759\end{array}$} & & \\
\hline B1 & 7 & $\mathrm{D}$ & 25 & & 9 & $\mathrm{D}$ & 19 & & 25,74 & Turun \\
\hline B1a & 11 & D & 25 & 5399,61 & 8 & D & 19 & 2268,23 & 57,99 & Turun \\
\hline B2 & 5 & D & 25 & 2454,37 & 9 & $\mathrm{D}$ & 19 & 2551,759 & 3,97 & Naik \\
\hline B3 & 7 & D & 19 & 1984,7 & 13 & D & 19 & 3685,874 & 85,71 & Naik \\
\hline B3a & 4 & D & 19 & 1134,11 & 10 & D & 19 & 2835,287 & 150 & Naik \\
\hline B4 & 5 & D & 25 & 2454,37 & 8 & $\mathrm{D}$ & 19 & 2268,23 & 7,58 & Turun \\
\hline B5 & 6 & D & 19 & 1701,17 & 8 & $\mathrm{D}$ & 19 & 2268,23 & 33,33 & Naik \\
\hline B6 & 6 & D & 19 & 1701,17 & 6 & $\mathrm{D}$ & 16 & 1206,372 & 29,09 & Turun \\
\hline $\mathrm{B}$ induk & - & - & - & - & 8 & $\mathrm{D}$ & 19 & 2268,23 & - & - \\
\hline B Anak & - & - & - & - & 7 & $\mathrm{D}$ & 16 & 1407,434 & - & - \\
\hline B Ring Balk & - & - & - & - & 15 & $\mathrm{D}$ & 19 & 4252,931 & - & - \\
\hline B Tie Beam & - & - & - & - & 15 & $\mathrm{D}$ & 19 & 4252,931 & - & - \\
\hline
\end{tabular}

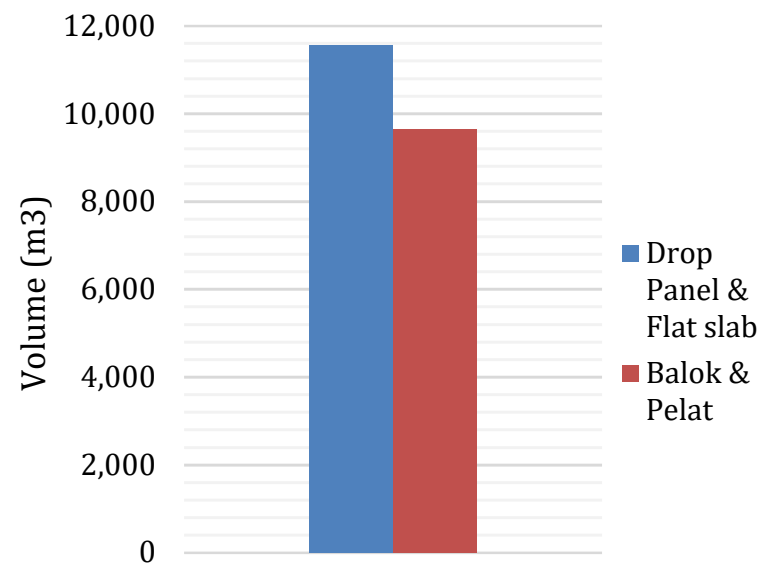

Gambar 14. Grafik Perbandingan Volume Beton

(Sumber : Analisis penulis 2020)

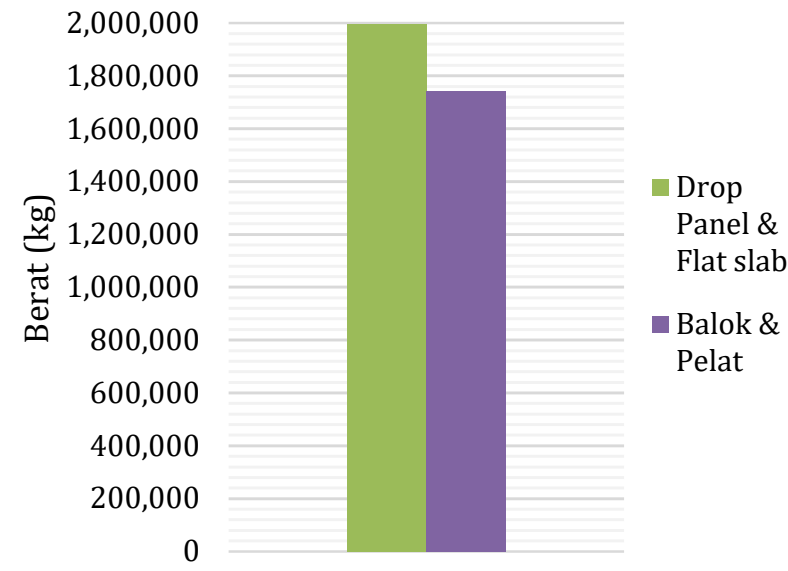

Gambar 15. Grafik Perbandingan Volume Tulangan Baja

( Sumber : Analisis penulis 2020) 


\section{Kesimpulan}

Berdasarkan hasil desain ulang struktur gedung Jogja apartemen didapat kesimpulan sebagai berikut :

1. Struktur bangunan yang didesain ulang menggunakan balok konvesional memiliki berat yang lebih ringan pada struktur pelat lantaimya sehingga dapat disimpulkan bangunan lebih aman terhadap parameter beban gempa yaitu baseshear, displacement, pengaruh P-Delta, dan ketidak beraturan struktur.

2. Pelat lantai yang mengalami penurunan ketebalan $(0,52$ persen $)$ memiliki volume pekerjaan beton yang lebih sedikit sebanding dengan penurunan ketebalan pelat lantai rasio tulangan baja pada pelat juga mengalami penurunan sebesar $(0,53$ persen $)$ sehingga dapat disimpulkan dalam pekerjaan pembesian pelat lebih cepat dibanding flat slab.

3. Balok desain ulang memiliki penurunan dimensi (33,2 persen) dibandingkan desain awal hal tersebut disebabkan berkurangnya beban pelat lantai karena penurunan ketebalan. Tulangan baja balok desain ulang juga mengalami penurunan sebesar $(39,06$ persen $)$ hal ini disebabkan karena tulangan baja menggunakan SNI 2052:2017 dengan mutu yang lebih tinggi dan juga berkurangnya beban dari pelat lantai.

4. Dari hasil perhitungan yang dilakukan volume beton desain ulang mengalami penurunan sebesar 16,274 \% dengan selisih 1896,46 $\mathrm{m}^{3}$ dan untuk volume tulangan baja juga mengalami penurunan sebesar 12,623 \% dengan selisih 251778,598 kg.

\section{Daftar Pustaka}

BSN. 2013. SNI 03-2847-2013: Persyaratan

Beton Struktural Untuk Bangunan Gedung. Bandung.

BSN. 2012. SNI 1726-2012: Tatacara Perencanaan Ketahanan Gempa untuk Struktur Bangunan Gedung dan Non Gedung. Bandung.

Budiono, B. dan Wicaksono, E. B., 2016, Perilaku Struktur Bangunan Dengan Ketidakberaturan Vertikal Tingkat Lunak Berlebihan Dan Massa Terhadap Beban Gempa, Jurnal Teknik Sipil, 23(2), 0853-2982.

Dovich, L. and Wight, J.K., 2005, Effective Slab width Model for Seismic Analysis of Flat Slab Frames, ACI Struktural Journal, 102(6), 868.

Eden, S., Aminullah, A. dan Andreas Triwiyono, A., 2019, Reinforced Concreate (RC) Beam Design Aplication for Android Based on SNI 2847:2013 (CEMA), MATEC Web of Conferences 258, SCESCM 2018.

Gunawan, A., Dewi, S. H. dan Adha, A., 2019, Studi Pengaruh Bukaan Corewall Terhadap Kinerja Lateral Sistem Struktur Yang Mengalami Beban Gempa, Jurnal Saintis, 19(1), 14107783.

Prabowo, A. dan Lase, Y., 2016, Tinjauan Nilai Faktor Modifikasi Respon (R) dan Faktor Kuat Lebih $(\Omega)$ Pada Struktur Gabungan Rangka Baja dan Rangka Beton Bertulang dengan Analisis Pushover, Jurnal Teknik Sipil, 23(1), 0853-2982.

Pudjisuryadi, P., Lumantarna, B., Setiawan, R. dan Handoko, 2018, Performance of an Existing Reinforced Concrete Building Designed in Accordance to Older Indonesian Seismic Code: visA Case Study for a Hotel in Kupang, 
Indonesia, Civil Engineering Dimension, 20(1), 1410-9530.

Sidi, I. D. dan Ma'sum, A. R., 2017, Keandalan menara televisi rangka baja akibat beban gempa. Jurnal Teknik Sipil, 24(3), 0853-2982.

Soelarso, S., dan Baehaki, B., 2017, Evaluasi Simpangan Struktur Akibat Penambahan Lantai dengan Metode Analisis Statik dan Dinamik Response Spectrum (Studi Kasus: Pembangunan Gedung Dekanat Fakultas Teknik UNTIRTA), Jurnal Spektran, 5(2), 23022590.

Sukrawa, M., 2014, Design Aspect of Including Infill Wall in RC Frame Design. Civil Engineering Dimension, 16(1), 1410-9530.

Viswanathan, T. S., Ganesh, G. M., and Santhi, A. S., 2014, Investigation of Shear Stud Performance in Flat Plate Using Finite Element Analysis, Journal of Engineering and Technological Sciences, 46(3), 328-341. 
